\title{
Educational role of language and Polish youth slang - literature review
}

\author{
Anna Dąbrowska \\ University of Warsaw; adabrowska@pedagog.uw.edu.pl
}

\begin{abstract}
The impact that language has on human cognitive processes unquestionably points to its educational value. A man acquires a language and through language learns the world. Thereby language becomes both the tool and the object of cognition. Language shapes the user's perception of the world as well as introducing them into a given linguistic and cultural community. Youth slang - being a socially-based language variety - primarily performs a social function. So far it has been classified as a lower language register of limited usage and therefore has not been studied with respect to its educational value. However, in the present-day cultural context youth slang becomes more commonly used and, consequently, the question What exactly does youth slang teach? seems vital. The article will cover the following problems: What is the educational role of language? What do we mean by educational role of language referring to the particular variety which is Polish youth slang?
\end{abstract}

Keywords: educational role of language, youth slang, functions of language, sociolect

\section{Introduction}

The significant contribution of language in cognitive processes indisputably indicates its educational role. People learn language and thanks to language they discover the world. Language thus becomes a tool and object of cognition. Language shapes the image of the world of its user and introduces him to a particular language and cultural society. In what area and in what way would its educational role be revealed? And can this term be used at all in the strict sense of the word with reference to language? Language is not an autonomous subject, which could set certain educational goals and then realize them. The question concerning the educational role of language will be referred to the specific part of language communication which is the sociolect of teenagers.

"Youth slang" mentioned in the title, which is a socially conditioned variety of language, has above all a social function. In Poland until recently it was treated as a lower register of language with limited use. Its educational significance was not considered. In today's cultural conditions the scope of its use is widening, hence the question What does youth slang teach?, is important.

In this article the following problem will be addressed What is the educational role of language? and What do we mean by educational role of language referring to the particular variety, which is Polish youth slang? In other words - In what way can the educational role of language be revealed through Polish youth slang?

\section{Educational role of language - how do we understand it?}

The expression "Educational Role of Language" contains two terms requiring consideration: educational and role. Education (in the strict sense) is understood as actions and processes as a whole, which aim to convey knowledge, shape certain qualities and skills. It thus presupposes the conscious undertaking of actions, which in a planned way lead to the realization of desired goals. In this sense language would not be able to fulfil an educational function, because it would not be able to consciously design and carry out planned actions.

As far as the term "role" is concerned, in the subject literature we can rather meet the category not "role of language", but "functions of language". Between the two terms can be seen a certain nuance of meaning. Function rather refers to specific tasks that language can carry out in culture, society and human communication and thought. The term "role" meanwhile underlines the significance of language in different areas. In this sense its educational character seems to be fully understandable. Even if in the subject literature there is no direct mention of the educational role of language, there are clear educational benefits of using language for researchers for whom it is the subject of academic consideration. It is this sense that we can discuss its educational role of language. The absence of any direct references in literature makes it necessary to pursue one's own research agenda. Classical concepts have been employed in this article to analyze various areas of language, showing to what 
extent the educational role penetrates each of its layers, creating an inseparable whole. Let us analyze functions of language, discovering areas in which its educational role is visible.

Human language from the structural point of view, which is understood as a conventional system of signs which are the basis for producing an infinite number of utterances, enabling communication, has two planes according to Ferdinand de Saussure (2004):

1. Langue is a code existing in the minds of the interlocutors, which enables communication. It is a system, composed of signs and rules, how to connect them in sentences, and sentences in whole texts, of which in theory there are an infinite number. Langue is a potential, which becomes real in communication.

2. Parole is the use of a language system - every "language behaviour" expressed by text or utterance.

Language, which is understood as a code, is general, social, limited in nature. Speech acts are specific, individual and unlimited. (Grzegorczykowa 2007:14) Concrete functions correspond to the planes of language.

Functions of langue:

1. Communicative (generative) - it enables communication, it constitutes the basis for producing and understanding texts by the interlocutors.

2. Cognitive - language becomes for its users a form of discovering the world; it becomes the representation of the world in their minds. It interprets reality, creating a linguistic image of the world. It constitutes a form of abstract thought.

Functions of parole:

Leaving aside particular functions of individual language use, the entirety of language actions of the society using the spoken language fulfils with regard to that society unique functions. These are not though conscious actions, but the role of the entirety of language actions observed ex post. We can distinguish two functions (Grzegorczykowa 1991):

1. Culture-forming - it involves gathering and storing knowledge in the form of written texts or utterances stored in the memory of the speakers.

2. Socializing - its aim is to unite members of a given society.

This socializing function we can easily refer to the particular variety of language, which is youth slang. This function will be discussed in the further part of this article.

\section{Where is the educational role of language reflected?}

In both areas mentioned above (in the planes langue and parole) the educational role of language can be noticed. As far as the plane langue is concerned, language is the basis of creating of communique and serves to aid understanding, while people learn by communication, a huge part of which is verbal. The discovery of the surrounding world, immediate and distant, as well as social reality takes place thanks to the possibility of communication, which is created by language.

According to E. Cassirer (1977), language enables people to think symbolically, it develops symbolic imagination. Thanks to linguistic means of communication people become symbolic beings, capable of considering abstract matters, far removed from "the here and now", capable of creating the plane of intercourse between generations. Ernst Cassirer named humans symbolic animals (Cassirer 1977: 8081). According to him people do not live only in the physical world, but also function in the symbolic world, which consists of: language, myth, art and religion. These are "different threads" from which the symbolic net is woven. We could say, that among these elements language is the basic material, thanks to which the others can develop. It is through language that a human's ability to create symbols is expressed. In the film "Quest for Fire" directed by Jean-Jacques Annaud there is a scene where the characters are trying to communicate and convey information about a storm, which took place earlier and during which a huge tree was blown over. The message concerns a different time and space from the communicative situation. In this way language is born. In order to convey essential information in this case a sign is needed. It allows people to refer to a remote context, but also to express abstract content - thoughts and ideas. Language is thus what differentiates humans from other living beings. 
Since language serves communication, a functioning language system must have sufficient potential to create utterances which meet the communicative needs of the users. Thus fulfilling the communicative (generative) function, it fulfils simultaneously the educational role for it users. Language is not a transparent, passive tool. Thought shapes language, and language shapes thought. Mutual interactions are present. H. G. Gadamer (1979) claims that language is not a tool. A tool is - of itself something whose use can be mastered: a tool can be picked up and put down when it has fulfilled its task. It might seem that the situation is similar in the case of language: we take in our mouth words of any language which are lying ready and we allow them to disappear again after use into the general collection of words which we have at our disposal. According to Gadamer this is not the same. It is a false analogy, because awareness never stands facing the world, picking up - in a languageless state as it were - a tool of communication. We are already embraced by language in all our knowledge about ourselves and the world. Every language classifies and interprets reality in a different way - for example by broadening lexis in a given field and minimizing it in another. A person immersed in a language might not even notice this fact. It is only knowing another language system and the different way of perceiving reality connected with it that leads to reflection.

The relationship between thought and language was considered and researched in connection with the Sapir-Whorf hypothesis, which is known as the hypothesis of linguistic relativism. According to it language is a social system, in which we grow up and think from childhood and which shapes our perception of the world. There are differences between individual language systems, which are a reflection of different environments constructing them; hence people thinking in different languages perceive the world in diverse ways. (Whorf 1982, Sapir 1978) A particular language through characteristic lexis and grammatical categories throws light on the reality surrounding its users and refers to its own cultural context. Language, constructing the representation in the human mind, teaches people to notice phenomena distinguished by language and interpret them in a certain way. This is an inseparable element of using language. In this way language directs human thought. Ludwig Wittgenstein (1997: 3) wrote that a limit to thought can only be set in language, and what lies on the other side is simply nonsense. The majority of thoughts are linguistic in character. Becoming aware of certain hitherto nonverbal intuitions, feelings and impressions happens when we try to name them, even if we alone receive the expressed content. This is why poor, primitive language speaks volumes about the way of thinking of its users, while rich communicative, precise language adapted appropriately to the situation as well as testifying to their way of thinking also "broadens" the horizons of the world. It is a perfect tool for deep reflection, without which it would be extraordinarily difficult. So enriching one's own language broadens the horizons of thought. J. Stewart (2010) even claims that a person's quality of life depends on the quality of communication. Everything people learn from others from the beginning of their life is acquired in the very communication process which is why a high communicative competence enriches and simplifies life, while a low competence can even lead to isolation.

The Educational Role of Language becomes apparent together with perfecting communicative competence (Hymes 1980, Kurcz 2000). Paraphrasing L. Wittgenstein, we can say that together with enriching language the user "broadens his/her horizons".

As far as the plane of parole is concerned and its culture-forming and socializing functions, in these areas too the educational role of language is visible. The culture texts and utterances contain knowledge about the world, which people gain by learning language. According to C. Levi-Strauss (2003) language introduces people into a particular culture, which they can only get to know fully when they know its language. Language introduces people into the social world, teaching them processes and relationships taking place in it. Language is the basis of culture, it is a conveyor belt of customs, traditions and values gathering common experiences of particular societies. It thus constitutes the source of getting to know individual cultures, and sometimes it is a mirror of social and cultural changes.

The educational role of language is revealed in its many diverse areas. It is not homogenous, however, but expressed in a variety of styles. This leads to the question whether and how its educational role may also be revealed in its different varieties? One of them is the style of 
communication typical of the youth. Let us now take a look at how the educational role of language can be expressed in the Polish youth slang.

\section{Educational role of Polish youth slang Polish youth slang - what is it?}

Youth slang is a socially conditioned variety of language, thus it is a sociolect. I define it, after S. Grabias, as a variety of language which is formed in the milieu of young people as a result of an expressive, spontaneous creativity in language (Grabias 1997: 141). In Poland, in the country quite homogeneous in terms of ethnicity, youth could successfully communicate by general Polish, but for specific reasons creates its own language. These reasons are social. According to Piekot, slang as a sociolect is simultaneously a social and a linguistic construct (Piekot 2008: 39).

\section{Functions and features of Polish youth slang}

Youth slang as a sociolect serves to integrate and distinguish a certain group, as well as to identify its members. It follows that those who aspire to or belong to a certain community use this sociolect and thanks to the use of the slang they build this community. Having its own language underlines the status of the group. The language created by the community interprets reality in a way which is in accord with their reception of the surrounding world and their values.

The specific features of youth slang are: creativity and connected with that changeability, its expressive and playful character (because it is built as a result of a play on words), as well as a resistance to the models conveyed by adults, and a note of secrecy serving to conceal transmitted content. According to H. Zgółkowa this tendency had diminished by 2012 (Zgółkowa 2012).

The features mentioned above foster the strengthening and constant updating of the group relations. The identification with the aid of the characteristic language of a certain community requires the knowledge of the current version of it, which involves communication and constant contact. Otherwise its use does not reflect membership of the group, and so it is not authentic.

The expressiveness is considered to be one of the most important features of youth slang. $\mathrm{M}$. Widawski claims that slang is the most colloquial, unconventional and expressive variety of language, in which the choice of elements of language is subsidiary to its expressiveness (Widawski 2010: XI). Its emotional character means that it stands out among the other varieties of language and in social consciousness it is connected with the milieu of young people. Thanks to the use of slang teenagers underline, sometimes even demonstrate, social bonds and express their judgement of reality. In youth slang often expression dominates over the meaning of particular words. The same word articulated with another intonation, in another context could express the same strong emotions but the opposite meaning. For example the phrase "What a babe!", depending on the situation can mean equally "pretty girl", as well as "not a very attractive girl" in the opinion of the speaker. In the example mentioned above in the foreground is the expressive function, not the informative function. It is a matter of expressing a judgement and attitude to the named person, behaviour or phenomenon in the way that is understandable, private and characteristic for the group. As a result one of the most important aims of the use of sociolectal phrases is maintaining and emphasizing the bonds of the community.

\section{Youth slang in the new cultural context and its educational role}

Youth slang was created by teenagers to communicate informally with their peers. Recently, however, we can notice a tendency for the use of the specific youth language to spread. J. Miodek points to the distinctness and expansiveness of youth slang (Bralczyk et al. 2014: 138). Over the last years in Poland some dictionaries of youth slang have appeared. For example ed. by B. Chaciński, H. Zgółkowa, P. Filciński and S. Wójtowicz, M. Widawski (Chaciński 2003, Zgółkowa 2004, Chaciński 2005, Filciński \& Wójtowicz 2007. Widawski 2010). According to J. Miodek a few decades ago the youth used to know slang, but it was considered to be the lower register of language and it was not the done thing to speak in this way outside a narrowly defined situation. Nowadays it is talked about and even promoted. Those who used it as teenagers, continue to use it, even when they grow up. 
The reasons for this relatively new phenomenon, the increasingly widespread use of youth sociolect, can be sought in the changing cultural context. Among them homogenization of the style of the representatives of different generations and the trend for being casual and young have a great significance. The fact that certain elements of the style of representatives of different generations is becoming gradually more uniform is a more and more noticeable feature of contemporary social reality. The style of dressing, taste in music, the choice of cultural activities are subject to the same mechanisms of popular culture. Both parents and their teenage children can wear jeans, T-shirts, listen to similar music and watch the same TV programme and at the same time parents use cool youth language to get through to their children. It is one of the ways in which youth slang is expanding.

Language is moreover one of the important elements of presenting oneself. Conscious use of youth slang by adults could be a strategy, whose objective is to build a certain image of oneself. In so doing the speaker presents him/herself as a laid-back person. Z. Melosik remarks the consumer culture is becoming prevalent and pleasure as well as a casual style are a compulsion (Melosik 2005: 14-15). With this style promoted by different media the style of communication is clearly evolving in the direction of using emotional colloquiality, even in formal, public situations or in asymmetric communication, for example: teacher - pupil. Simultaneously there is increasing approval for the use of the laid-back, teenage style of utterances by adults in different communicative situations.

In the face of the cultural conditions favouring the expansion of teenagers' sociolect it is worth considering its educational role. There are at least a few instances of it.

Youth slang is created in opposition to formal language. It is connected with contestation. It enriches the Polish language, because it has added many new words to the general Polish language. Youth slang strengthens the phenomenon of stylistic variety in language and fulfils different social functions. A young person begins to become aware very early on of the internal variety of language and the need to use different language styles depending on context and communicative situation. Using slang in the correct way gives him the opportunity to perfect the skills of a stylistically appropriate language communication. Young people learn in what situation, with which interlocutor to use a specific variety of language - formal, informal or for example slang.

Knowing another language or another variety of it is meeting another image of the world contained in it. Slang gives a chance to see reality in another way, maybe hitherto unknown to the user of language. This happens through the prism of the experiences of the community speaking this language, which encapsulated and crystalized its values and perception of the world in its own language.

Distinguishing any phenomenon through slang makes pupils aware of its existence. For example the word "dysgooglia" (dys + google). It is built by analogy with "dyslexia" and "dysgraphia" and means a certain dysfunction. In this case it concerns a lack of skill in searching for necessary information in the internet. The language, which is a mirror of cultural changes reflects in this way new tendencies.

The evaluation contained in the sociolect, which is visible through the emotional and evaluative character of the lexis of slang, unifies the attitude of members of the community to the people or phenomena described. It happens like that in the case of the words "brown-nose", "brown-nosing", which means to be polite in order to gain a benefit. Not only do they point to the existence of a certain stance, but their contemptuous resonance makes the members fully aware of the negative assessment.

Slang makes members conscious of the existence of the community and it is an external sign of belonging to it. Elaborating its own language by the group is evidence of its position, as it requires constant updating and frequent contacts. A young person, if he/she wants to join the community, should learn and use its language. It is one of the criteria of identification: familiar - unfamiliar (stranger).

Furthermore slang could be a perfect source of knowledge for scholars about the community speaking that language, about how it perceives the surrounding reality, for example the reception of school as oppressive in slang. This is evidenced by slang words regarding school and teachers, drawing on prison metaphors: school as - ... prison, pupil as a prisoner, question at the blackboard as execution, conviction, the end of the schoolyear - freedom at last. This way of reception is included in a slang expression, for example: School is like a police station. They interrogate you, and you don't know 
anything. School is like a toilet. You go, because you have to. School is like a lottery. Millions of chances, no wins (Wileczek 2011: 168-169).

\section{Conclusion}

Language as a social construct plays a certain role with regard to people. This is a tool for communication, so it enables cognition of reality through, obtaining information, exchanging thoughts, as Austin (2006) wrote, we have access to the thoughts of other people thanks to language. Language is not completely transparent and together with acquiring language people receive a particular proposition of the reception of reality. This is an image seen through the prism of that language.

Language relates a person to a particular community and thanks to that it is a sign and also an element shaping his/her identity as well as being the key to participation in a given culture. In language communication a person discovers the characteristic nature of the language and cultural community, as well as becoming aware of being a part of it. People present themselves through utterance and written communique. Speaking or writing, they do not only convey certain content, but also communicate a great deal about themselves. The conscious choice of certain elements of language, lexis and structures, for example slang, during the utterances can constitute an integral part of the creation of their own image. All these elements contribute to the educational role of language.

Awareness of the existence of various socially conditioned varieties of language, including youth slang, helps identify the existence of well-consolidated communities functioning within the linguistic and cultural society. Through the use of its own language, a community becomes integrated and gives expression to its values. Young people read them, and by learning its language also learn to understand the community. The correct use of youth slang may also be an expression of the user's communicative competence, demonstrating his or her ability to adapt to the other person's way of speaking and to the communicative situation. The educational role of slang is therefore realized through the communicative practice of persons for whom it represents a way of drawing on the riches of linguistic expression.

\section{References}

Austin, J. L. (2006). Mówienie i poznawanie. Rozprawy i wykłady filozoficzne, przekł. B. Chwedeńczuk. Warszawa, Wydawnictwo Naukowe PWN.

Bernstein, B. (1990). Odtwarzanie kultury, przekł. Z. Bokszański, A. Piotrowski.Warszawa, PIW.

Bralczyk, J., Miodek, J., Markowski, A. \& Sosnowski, J. (2014). Wszystko zależy od przyimka. Bralczyk, Miodek, Markowski w rozmowie z Jerzym Sosnowskim. Warszawa, Agora SA.

Cassirer, E. (1977). Esej o człowieku: wstęp do filozofii kultury, przeł A. Staniewska. Warszawa, Czytelnik.

Chaciński, B. (2003). Wypasiony słownik najmłodszej polszczyzny. Kraków, Znak.

Chaciński, B. (2005). Wyczesany słownik najmłodszej polszczyzny. Kraków, Znak.

Filciński, P. \& Wójtowicz, S. (2007). Hip-hop. Słownik. Warszawa, Wydawnictwo Naukowe PWN.

Gadamer, H. G. (1979). Człowiek i język. W: H.G. Gadamer, Rozum, słowo, dzieje. Szkice wybrane, przeł. M. Łukasiewicz, K. Michalski. Warszawa, PIW.

Grabias, S. (1997). Język w zachowaniach społecznych. Lublin, Wydawnictwo Uniwersytetu Marii CurieSkłodowskiej.

Grzegorczykowa, R. (1991). Problem języka i funkcji tekstu w świetle teorii aktów mowy. In J. Bartmiński \& R. Grzegorczykowa (Eds.), Język a kultura (pp. 11-28). Wrocław, Wydawnictwo Wiedza o Kulturze.

Hymes, D. (1980). Socjologia i etnografia mówienia, przeł. K. Biskupski. In M. Głowiński (Ed.), Język i społeczeństwo. Warszawa, Czytelnik.

Kaczmarek, L., Skubulanka, T. \& Grabias, S. (1994). Słownik gwary studenckiej. Lublin, Wydawnictwo Uniwersytetu Marii Curie-Skłodowskiej.

Kowalikowa, J. (1991). Sygnały i nośniki humoru w języku mówionym uczniów krakowskich. W: J. Porayski-Pomsta (red.), Zagadnienia komunikacji językowej dzieci i młodzieży. Warszawa, Wydawniczy i Handlowy „ELIPSA”.

Kurcz, I. (2000). Psychologia języka i komunikacji. Warszawa, Wydawnictwo Naukowe „Scholar”.

Levi-Strauss, C. (2003). Kultura i język, przeł. J. Trznadel. W: G. Godlewski, A. Mencwel, R. Sulima (red.), Antropologia słowa. Warszawa, Wydawnictwa Uniwersytetu Warszawskiego.

Melosik, Z. (2005). Młodzież a przemiany kultury współczesnej. W: R. Leppert, Z. Melosik, B. Wojtasik (red.), Młodzież wobec niegościnnej przyszłości. Wrocław, Wydawnictwo Naukowe Dolnośląskiej Szkoły Wyższej Edukacji TWP we Wrocławiu. 
Miodek, J. (2012). Polszczyzna różnych pokoleń. W: A. Markowski, R. Pawelec (red.), Oblicza polszczyzny. Warszawa, Wyd. Narodowe Centrum Kultury.

Piekot, T. (2008). Język w grupie społecznej: wprowadzenie do badań socjolektów. Wałbrzych, Wydawnictwo Państwowej Wyższej Szkoły Zawodowej im. Angelusa Silesiusa w Wałbrzychu.

Sapir, E. (1978). Kultura, język, osobowość. Wybrane eseje, przeł. B. Stanosz, R. Zimand. Warszawa, PIW.

Saussure, F. (2004). Szkice z językoznawstwa ogólnego, przeł. M. Danielewiczowa.Warszawa, Wydawnictwo Akademickie DIALOG.

Stewart, J. (2010). Mosty zamiast murów: podręcznik komunikacji interpersonalnej, przeł. J. Suchecki. Warszawa, Wydawnictwo Naukowe PWN.

Whorf, B. L. (1982). Język, myśl i rzeczywistość, przeł. T. Hołówka. Warszawa, PIW.

Widawski, M. (2010). Slang UG. Słownik slangu studentów Uniwersytetu Gdańskiego. Gdańsk, Wydawnictwo Uniwersytetu Gdańskiego.

Wileczek, A. (2011). Czy szkoła „zdanża”? Językowy obraz szkoły w socjolekcie młodzieżowym. W: M. Bajan, S.J. Żurek (red.), Etyka nauczyciela. Lublin, Towarzystwo Naukowe Katolickiego Uniwersytetu Lubelskiego Jana Pawła II.

Wileczek, A. \& Możdżonek, I. (2015). Szkolna niekomunikacja. Bariery w dyskursie wczesnoszkolnym. Warszawa, PWN.

Wittgenstein, L. (1997). Tractatus logico - philosophicus, przeł. B. Wolniewicz. Warszawa, Wydawnictwo Naukowe PWN.

Zgółkowa, H. (2004). Nowy słownik gwary uczniowskiej. Wrocław, Wydawnictwo EUROPA.

Zgółkowa, H. (2012). Gwara uczniowska (szkolna) w poszukiwaniu inspiracji. W: A. Markowski, R. Pawelec (red.), Oblicza polszczyzny. Warszawa, Wyd. Narodowe Centrum Kultury.

Laboratorium językowe. Korpus języka młodzieży początku XXI wieku. http://www.laboratoriumjezykowe.uw.edu.pl/. Accessed on 21 September 2018.

Slang młodzieżowy. Słownik internetowy. www.miejski.pl. Accessedo on 21 September 2018. 